BAKTIMAS

Jurnal Pengabdian pada Masyarakat
Vol. 2, No. 1,

Maret 2020
eISSN 2685-113x

pISSN 2685-0303

\title{
Pelatihan Penggunaan Mendeley dan Pemaparan Pembuatan Artikel Bagi Guru di Kabupaten Indramayu
}

\author{
Denni Ismunandar ${ }^{1}$, Farid Gunadi ${ }^{2)}$ \\ ${ }^{1,2}$ Program Studi Pendidikan Matematika Universitas Wiralodra, Jl. Ir. H. Djuanda KM. 3 Indramayu \\ Email : denni.ismunandar@unwir.ac.id, farid.gunadi@unwir.ac.id
}

DOI : 10.32672/btm.v2i1.2031

\begin{abstract}
Teachers are one important element in the world of education. Teacher competencies are always be preferred to support students' cognitive development. Variative learning methods, learning strategies, and various assessment methods to do for students' cognitive, psychomotor and affective abilities can develop. Competent teachers are not only based on length of teaching, but now competent teachers are teachers who carry out Classroom Action Research (CAR) to improve student abilities and report the results of the research through direct reports and use articles published in national journals. In this service program, the team conducted Mendeley's use training and presentation on writing articles to assist the teacher in compiling articles to be published in a journal. The purpose of this service is to help teachers turn CAR into an article that is worth publishing. The method used is the lecture method. The results of this dedication are the report on the implementation of the dedication team in providing training using mendeley and presentation of article making. The limitation of the implementation of this dedication is the time given only 1 hour, because the teacher is only willing to come after turning from school. Therefore, the results of this service are only in the form of reports on the implementation of community service performed by the team.
\end{abstract}

Keywords: Mendeley, article, discourse method.

\begin{abstract}
ABSTRAK
Guru adalah salah satu elemen penting dalam dunia pendidikan. Kompetensi guru selalu dinomor satukan untuk mendukung perkembangan kognitif siswa. Metode pembelajaran yang variatif, strategi pembelajaran, dan bermacam cara penilaian dilakukan supaya kemampuan kognitif, psikomotorik dan afektif siswa dapat berkembang. Guru yang berkompeten tidak hanya berdasarkan lama mengajar, namun sekarang ini guru yang berkompeten adalah guru yang melaksanakan Penelitian Tindakan Kelas (PTK) untuk memperbaiki kemampuan siswa dan melaporkan hasil penelitian tersebut melalui laporan secara langsung dan menggunakan artikel yang diterbitkan di jurnal berskala nasional. Pada program pengabdian ini, tim melakukan pelatihan penggunaan Mendeley dan pemaparan pembuatan artikel untuk membantu guru dalam menyusun artikel yang akan diterbitkan ke suatu jurnal. Tujuan dari pengabdian ini adalah membantu guru mengubah PTK menjadi suatu artikel yang layak diterbitkan. Metode yang dilaksanakan menggunakan metode ceramah. Hasil pengabdian ini adalah laporan
\end{abstract}


BAKTIMAS

Jurnal Pengabdian pada Masyarakat
Vol. 2, No. 1,

Maret 2020
eISSN 2685-113x

pISSN 2685-0303

pelaksanaan tim pengabdian dalam memberikan pelatihan menggunakan mendeley dan pemaparan pembuatan artikel. Keterbatasan pelaksanaan pengabdian ini adalah waktu yang diberikan kepada tim hanya 1 jam, karena guru hanya bersedia datang setelah pulang dari sekolah. Oleh karena itu hasil pengabdian ini hanya berupa laporan pelaksanaan pengabdian masyarakat yang telah dilakukan oleh tim.

Kata kunci: Mendeley, artikel, metode ceramah.

\section{PENDAHULUAN}

Indramayu merupakan sebuah daeraah di Jawa Barat yang sebagian besar wilayahnya berupa pertanian. Sebagian besar penduduk yang bertempat tinggal di Indramayu berpencaharian sebagai buruh petani. Selain itu, penduduk Indramayu bermata pencaharian sebagai buruh kapal dan nelayan serta sebagian sebagai guru, PNS, dan berwirausaha. Kondisi seperti ini kurang baik untuk bidang pendidikan, karena penghasilan buruh tani dan buruh nelayan tidaklah terlalu besar sehingga berdampak pada gaji guru non PNS yang kurang memenuhi standar UMK. Hal ini mengakibatkan beberapa guru non PNS mengejar sertifikasi melalui PTK dan publikasi hasil PTK.

Menurut UU Nomor 14 tahun 2005, Guru adalah pendidik profesional dengan tugas utama mendidik, mengajar, membimbing, mengarahkan, melatih, menilai, dan mengevaluasi peserta didik pada pendidikan anak usia dini jalur pendidikan formal, pendidikan dasar, dan pendidikan menengah. Pendidikan menengah yang dimaksud adalah pendidikan ditingkat SMP dan SMA. Salah satu tugas seoraang guru adalah mengevaluasi siswanya sehingga siswa yang kurang hasil belajarnya dapat ditingkatkan hasil belajar siswa tersebut melalui evaluasi yang dilakukan oleh guru.

Evaluasi yang dilakukan bukan hanya evaluasi terhadap hasil pekerjaan siswa, namun guru juga mengevaluasi bagaimana cara mengajar dirinya sendiri dan bagaimana keadaan siswa jika diberikan metode pembelajaran yang berbeda. Oleh karena itu, guru yang hebat dapat mengubah siswa dari yang belum tahu menjadi tahu, dari siswa yang malu bertanya menjadi aktiv bertanya, dan dari siswa yang rendah diri menjadi berprestasi. Hal ini dapat dilakukan pada guru yang melakukan evaluasi. Evalusi tersebut biasa disebut dengan PTK atau penelitian tindakan kelas. Menurut Gunada, Harjono, \& Gunawan (2018), PTK dapat membantu guru memperbaiki mutu dalam mengajar, menambah percaya diri, serta mengembangkan pengetahuan dan ketrampilan guru dalam mengajar.

Dalam melakukan penelitian, seorang guru harus memperhatikan silabus, kurikulum, pendidikan, buku panduan guru, penilaian dan hal lain yang harus bersesuaian dengan PP Nomor 32 tahun 2013. Oleh karena itu, sebelum melakukan penelitian, guru harus menyusun rancangan pengajaran atau yang disebut dengan RPP. Hal ini selaras dengan Peraturan Menteri Negara Pendayagunaan Aparatur Negara Dan Reformasi Birokrasi Nomor 16 Tahun 2009 pasal 6 bahwa guru wajib melaksanakan pembelajaran/ bimbingan serta melakukan perbaikan dan pengayaan. Pada pasal 8 disebutkan pula bahwa guru berwenang memilih dan menentukan materi, strategi, metode, media pembelajaran/bimbingan sesuai dengan kode etik profesi guru. Penelitian yang dilakukan oleh seorang guru akan memberikan dampak pada penilaian kinerja pada seorang guru. Menurut Slameto, Bambang S. Sulasmono, Krisma Widi 
Wardani (2017), upaya peningkatan kinerja guru dapat dilakukan melalui pendidikan dan pelatihan. Hasil pengabdian Widagdo \& Susilo (2018), menyatakan bahwa pelatihan penulisan artikel ilmiah dapat meningkatkan profesionalisme guru. Berdasarkan peraturan pemerintah, penelitian, dan pengabdian kepada masyarakat yang telah dilakukan, maka tim PKM akan melakukan pelatihan Mendeley dan pemaparan pembuatan artikel bagi guru SMP di Indramayu.

\section{Permasalahan Mitra}

Hasil wawancara yang dilakukan tim pengusul kepada beberapa guru, diantaranya, asisten wakasek kurikulum dan guru mata pelajaran matematika. Permasalahan yang dihadapi oleh guru - guru terkait dengan penelitiaan dan penulisan artikel adalah sebagai berikut. (1) Kurangnya pelatihan mengenai penelitian tindakan kelas; (2) Kuranganya bimbingan mengenai metodologi penelitian; (3) Kurangnya bimbingan dalam menulis laporan penelitian tindakan kelas; (4) Belum ada pelatihan penulisan artikel untuk dipublikasikan

Berdasarkan masalah yang di atas, dapat disimpulkan bahwa guru membutuhkan pelatihan dalam membuat sebuah artikel. Salah satu langkah untuk mengatasi masalah tersebut adalah dilakukan pelatihan. Namun karena keterbatasan kemampuan tim PKM, maka pelatihan hanya dapat dilakukan pelatihan penulisan artikel untuk dipublikasikan

\section{METODE}

\section{Bentuk Kegiatan}

Kegiatan pengabdian masyarakat dilaksanakan dalam bentuk ceramah. Kegiatan dilaksanakan selama 1 jam dengan beberapa tahap penyampaian materi. Tahap pertama, tim memberikan materi bagaimana membuat artikel dari hasil PTK yang telah dilaksanakan oleh guru. Penyampaian materi ini selama 20 menit, karena dari pendahuluan hingga penutup para peserta/ guru telah memahami isi dari pendahuluan hingga penutup. Tim hanya sedikit memberikan materi mengenai isi dari pendahuluan, metode sertaa hasil dan pembahasan. Tahap ke dua, pelatihan Mendeley. Pertama, pesertaa diminta untuk membuat email bagi yang belum punya dan mengecek email terkait dengan masih aktiv atau tidak email yang digunakan. Langkah selanjutnya adalah mengikuti arahan tim pelaksana pengabdian kepada masyarakat.

\section{Tujuan dan Sasaran Kegiatan}

Kegiatan bertujuan meningkatkan kemampuan guru SMP dalam membuat artikel. Program, tujuan dan sasaran kegiatan ini tercantum pada tabel 1 berikut. 
BAKTIMAS

Jurnal Pengabdian pada Masyarakat
Vol. 2, No. 1,

Maret 2020
eISSN 2685-113x

pISSN 2685-0303

Tabel 2. Program, Tujuan, Sasaran dan Materi kegiatan

\begin{tabular}{|c|l|l|l|l|}
\hline N0 & \multicolumn{1}{|c|}{ Program } & \multicolumn{1}{|c|}{ Tujuan } & Sasaran & \multicolumn{1}{c|}{ Materi } \\
\hline 1 & Pelatihan Mendeley & $\begin{array}{l}\text { Peserta mampu } \\
\text { menggunakan software } \\
\text { Mendeley dalam mengutip } \\
\text { dan penulisan dalam daftar } \\
\text { pustaka }\end{array}$ & $\begin{array}{l}\text { Guru } \\
\text { Matema } \\
\text { tika } \\
\text { SMP }\end{array}$ & $\begin{array}{l}\text { Instal Mendeley } \\
\text { Pengisian Identitas di } \\
\text { Mendeley } \\
\text { Menggunakan } \\
\text { Kutipan di Mendeley }\end{array}$ \\
\hline 2 & $\begin{array}{l}\text { Pemaparan } \\
\text { pembuatan artikel }\end{array}$ & $\begin{array}{l}\text { Peserta mampu mengubah } \\
\text { hasil PTK menjadi artikel } \\
\text { yang siap untuk } \\
\text { dipublikasikan }\end{array}$ & $\begin{array}{l}\text { Guru } \\
\text { Matema } \\
\text { tika } \\
\text { SMP }\end{array}$ & $\begin{array}{l}\text { Pembuatan artikel } \\
\text { dari hasil PTK }\end{array}$ \\
\hline
\end{tabular}

\section{Tujuan Pelatihan}

Adapun tujuan dilaksanakan pelatihan adalah sebagai berikut:

1. Mengetahui kemampuan guru dalam membuat artikel

2. Meningkatkan publikasi ilmiah guru dari hasil PTK yang telah dilaksanakan

3. Mengetahui kendala yang dialami guru dalam membuat artikel.

\section{Waktu dan Tempat Kegiatan}

Kegiatan pelatihan/workshop dilaksanakan selama 1 hari, yaitu pada 10 Januari 2020 Persiapan dilakukan selama 2 bulan yaitu pada bulan November dan Desember. Pelaporan hasil kegiatan pada bulan April dan publikasi hasil pengabdian pada bulan Mei 2020.

\section{Peserta Kegiatan dan Nara Sumber}

Peserta terdiri dari guru - guru SMP baik negeri maupun swasta di Kabupaten Indramayu. Jumlah peserta sebanyak 20 guru. Nara sumber adalah tim pengabdian masyarakat, yaitu Denni Ismunandar, S.Si., M.Pd.

\section{Sarana dan Alat yang Digunakan}

Pelatihan diselenggarakan dengan menggunakan sarana ruang kelas di salah satu ruang kuliah di Universitas Wiralodra. Ruangan dilengkapi peralatan seperti laptop, proyektor, dan kursi meja sebagai pendukung berjalannya proses pelatihan. Selama pelatihan berlangsung disampaikan beberapa materi mengenai materi instalasi dan penggunaan Mendeley serta pemaparan pembuatan artikel yang disampaikan melalui proyektor.

\section{PEMBAHASAN}

Kegiatan pengabdian ini hanya berupa laporan kegiatan. Beberapa laporan yang akan diberikan adalah sebagai berikut. 
Denni Ismunandar, Farid Gunadi

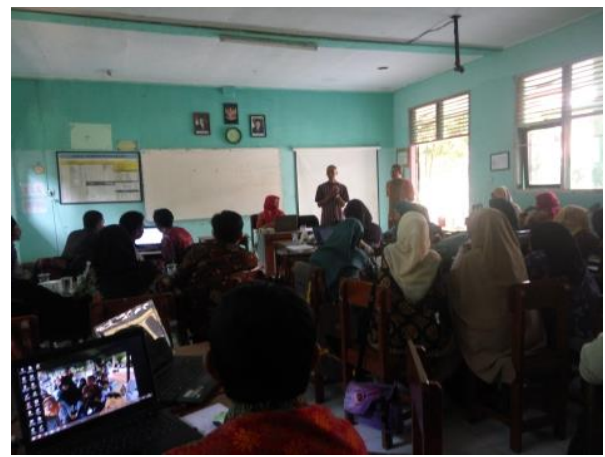

Gambar 1. Foto Kegiatan pelatihan mendeley

Gambar 1 merupakan pemaparan tim pengabdian kepada guru - guru. Para guru memperhatikan arahan bagaimana menginstal mendeley dan menggunakan software mendeley.

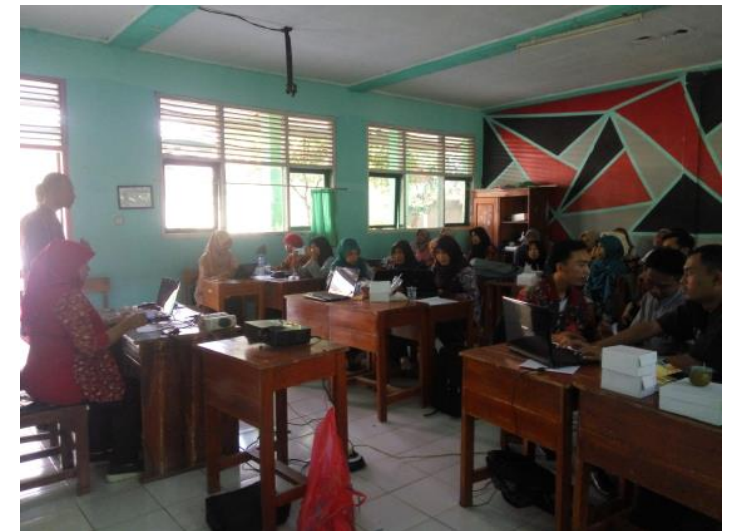

Gambar 2. Foto Kegiatan pelatihan mendeley

Gambar 2 merupakan pemaparan tim pengabdian kepada guru - guru terkait dengan bagaimana membuat artikel dari hasil Penelitiaan Tindakan Kelas yang telah dilaksanakan oleh guru.

\section{Evaluasi Kegiatan}

Kegiatan evaluasi dilakukan setelah selesai kegiatan. Evaluasi pelaksanaan pengabdian ini adalah kurangnya koordinasi dengan guru - guru SMP. Hal ini dikarenakan tidak adanya kesepakatan terkait dengan hari pelaksanaan pengabdian. Kekurangan yang lain dalam pelaksanaan pengabdiaan ini adalah waktu yang diberikan hanya $1 \mathrm{jam}$, sehingga pelaksanaan pengabdian kurang maksimal

\section{DAFTAR PUSTAKA}

Gunada, I. W, Harjono, A., \& Gunawan. (2018). Pelatihan Mendesain Penelitian Tindakan Kelas dan Pengembangan Model Dick And Carey Bagu guru - Guru di SMA Negeri 1 Narmada. Jurnal Pendidikan dan Pengabdian Masyarakat. Vol. 1, No. 1, 150-158. 
BAKTIMAS

Jurnal Pengabdian pada Masyarakat
Vol. 2, No. 1,

Maret 2020
eISSN 2685-113x

pISSN 2685-0303

Peraturan Menteri Negara Pendayagunaan Aparatur Negara Dan Reformasi Birokrasi Nomor 16 Tahun 2009 Tentang Jabatan Fungsional Guru Dan Angka Kreditnya.

Peraturan Pemerintah Republik Indonesia Nomor 32 Tahun 2013 Tentang Perubahan Atas Peraturan Pemerintah Nomor 19 Tahun 2005 Tentang Standar Nasional Pendidikan.

Undang-Undang Republik Indonesia Nomor 14 Tahun 2005 Tentang Guru Dan Dosen

Slameto, Bambang S. Sulasmono, Krisma Widi Wardani. (2017). Peningkatan Kinerja Guru Melalui Pelatihan Beserta Faktor Penentunya. Jurnal Pendidikan Ilmu Sosial, VOL 27, NO.2, $38-47$.

Widagdo, A., Susilo. (2018). Pelatihan Penulisan Artikel Ilmiah Bagi Guru-Guru SD di Kecamatan Kendal. Abdimas Unwahas. Vol. 3, No. 3, 25-29. 